\title{
Respon masyarakat terhadap rencana pemanfaatan galian tambang pasir sebagai wahana wisata kolam pancing
}

\author{
A. Mafaza Kanzul Fikri ${ }^{1)^{*}}$, Wachju Subchan ${ }^{1)}$, Sudarti $^{1)}$ \\ ${ }^{1)}$ Universitas Jember \\ aankfikri45@gmail.com
}

Abstrak: Tujuan dari penelitian ini adalah untuk mengetahui dampak bekas galian tambang pasirdesa Badean kecamatan Rogojampi kabupaten Banyuwangi dan untuk pemanfaatan bekas galian tambang pasir sebagai wahana wisata kolam pancing warga disekitar tambang pasir. Metode yang digunakan dalam penelitian ini menggunakan metode analisis deskriptif kualitatif. Untuk melengkapi penelitian ini, penulis menggunakan data primer yang diperoleh melalui komunikasi langsung dengan responden yaitu warga sekitar tambang pasir. Populasi sampel adalah warga masyarakat disekitar tambang pasir didesa Badean Kecamatan Rogojampi Kabupaten Banyuwangi. Sampel yang diambil menggunakan metode purposive sampling area dan untuk metode pengambilan datanya dengan cara documentasi, observasi dan mengajukan kuisioner pertanyaan terhadap warga sekitar tambang pasir. Dari hasil penelitian yang dilakukan, menunjukkan bahwa kegiatan penambangan pasir berdampak negative, dikarenakan sangat merugikan warga sekitar. Dampak negative tersebut diantaranya jalan umum menjadi rusak, ada beberapa korban jiwa terutamanya anak kecil yang tenggelam di bekas galian tambang pasir dan masih banyak lainnya. Peneliti juga melakukan upaya memberi solusi supaya bekas galian pasir tersebut menjadi bermanfaat bagi warga sekitar dengan cara mengubah bekas galian tambang pasir tersebut menjadi wahana wisata kolam pancing dan hasil wawancara terhadapat masyarakat sekitar tambang merespon sangat baik dan menyetujuinya.

Kata Kunci: Tambang Pasir, dampak, dan pemanfaatan.

\section{PENDAHULUAN}

Sumber Daya Alam (SDA) adalah unsur-unsur yang terdiri dari SDA nabati (tumbuhan) dan SDA hewani (satwa) dengan unsur non hayati di sekitarnya yang secara keseluruhan membentuk ekosistem (KEHATI, 2009). Setiap wilayah di muka bumi memiliki potensi sumber daya alam yang berbeda-beda. Indonesia merupakan salah satu negara di dunia yang kaya akan sumber daya alam, baik sumber daya alam hayati maupun non hayati. Hal ini menjadi salah satu keunggulan apabila sumber daya alam yang ada dimanfaatkan secara optimal. Salah satu sumber daya alam yang ada di Indonesia ada di sektor pertambangan. Mulai dari pertambangan emas, batu bara, dan pasir. Kegiatanpertambangan sudah sangat berkembang, hasil yang diberikanpunmemberikan keuntungan bagi peningkatan kesejahteraan hidup masyarakat, khususnya bagi para penambang. Meskipun demikian, kegiatan yang menjanjikan ini turut pula membawa dampak yang merugikan bagi manusia dan lingkungan hidup manakala kegiatan tersebut tidak dilakukan berdasarkan peraturan yang telah ditetapkan, yaitu kegiatan pertambangan yang dilakukan tanpa izin yang diberikan instansi yang berwenang.

Penambangan adalah bagian kegiatan usaha pertambangan untuk memproduksi mineral dan/atau batu bara dan mineral ikutannya. Pertambangan mineral adalah pertambangan kumpulan mineral yang berupa bijih atau batuan, di luar panas bumi, minyak dan gas bumi, serta air tanah (Salim, 2014). Penambangan pasir adalah penggalian di bawah permukaan tanah baik di lahan ataupun di bawah tanah aliran sungai dengan maksud pengambilan jenis bahan galian mineral non logam berupa pasir yang mempunyai arti ekonomis (Salim, 2014).

Salah satu tambang yang cukup banyak dikandung bumi Indonesia ini yaitu tambang pasir. Bahan pasir merupakan salah satu bahan baku utama untuk bangunan sipil seperti rumah, gedung, jalan, jembatan, 
pelabuhan, bendungan dan lain-lain. Bahan pasir digunakan untuk memenuhi kebutuhan masyarakat lokal maupun di luar daerah tersebut. Kecamatan Rogojampi merupakan salah satu kecamatan yang berada di wilayah kabupaten Banyuangin Provinsi Jawa Timur yang memiliki potensi mineral non logam, hal tersebut dibuktikan dengan adanya lokasi penambangan pasir. Lokasi penambangan pasir di Kecamatan Rogojampi bisa ditemui di desa badean, Gumuk agung dan Cangkring yang masih berda dalam kawasan kecamatan Rogojampi kabupaten Banyuwangi Provinsi Jawa Timur.
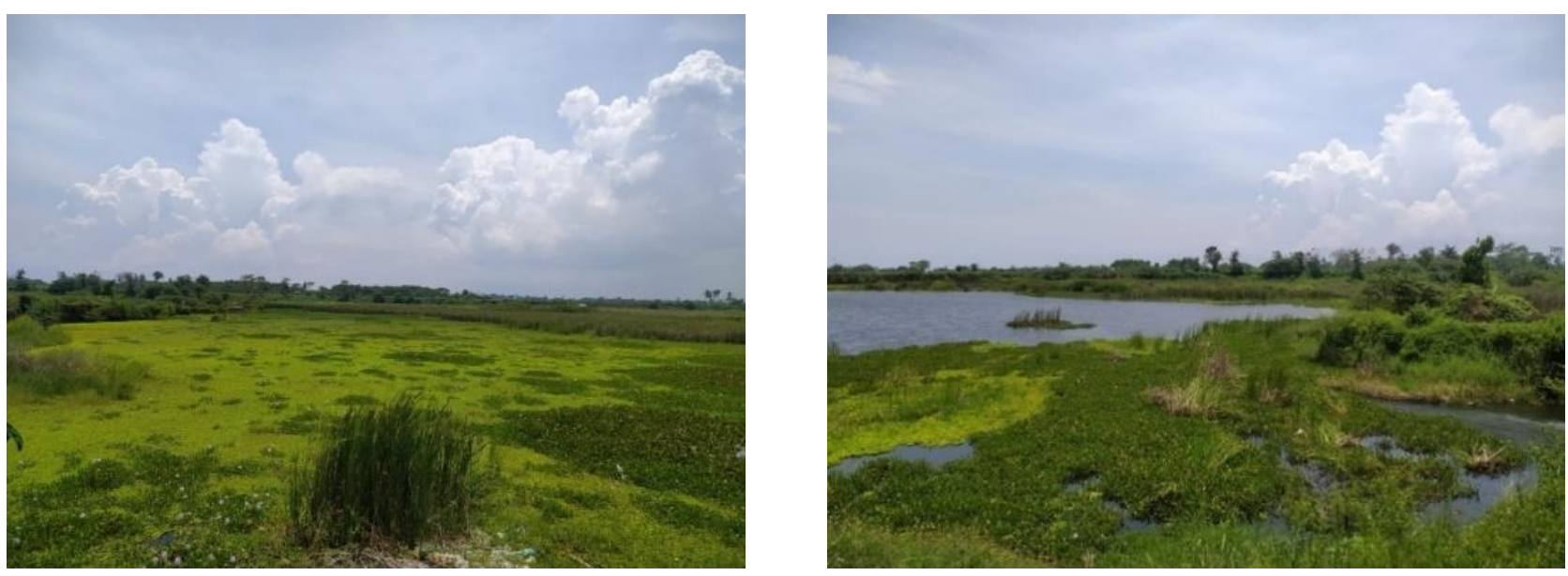

Gambar 1. Lokasi Bekas Galian Tambang Pasir di desa Badean Rogojampi

Aktivitas penambangan pasir pada dasarnya dilakukan untuk memenuhi kebutuhan manusia di bidang infrastruktur baik untuk pemukiman maupun transportasi (Irfan Ido, 2019). Namun tidak dapat dipungkiri bahwa secara langsung maupun tidak langsung dapat berdampak pada kehidupan manusia dan lingkungan sekitarnya, baikkerusakan ekologi maupun ekonomi dan sosial budaya. Kajian tentang aktivitas penambangan pasir bisa berdampak positif seiring dengan peningkatan kesejahteraan masyarakat setempat karena dapat memperoleh penghasilan tambahan (Muhammad Akbar., Zainal Said., \& R. Rusnaena, 2019), antara Rp. 400.000,00 - Rp. 1.000.000,00 per bulan. Penggalian pasir yang dilakukan secara individu atau kelompok menjadi sumber pendapatan baru karena dibeli langsung oleh pelaksana proyek.

Selain berdampak positif baik secara ekonomi maupun sosial, penambangan pasir juga menimbulkan konflik horizontal akibat kerusakan ekologis. Kelompok masyarakat yang tanahnya terkena proyek pertambangan menjadi bagian dari pekerja tambang dan mendapatkan ganti rugi. Sedangkan kelompok yang tanahnya tidak terkena proyek pertambangan, selain tidak menerima kompensasi keuntungan dan pekerjaan penambangan, juga merasakan kerusakan lingkungan yang mengakibatkan konflik horizontal antara kedua belah pihak (Refki Hontong., Antonius Purwanto., \& Juliana Tumiwa, 2016). Sementara itu, konflik akibat aktivitas penambangan pasir juga tidak bisa dihindari antara masyarakat, pengembang, dan pemerintah. Diperlukan solusi, yaitu pendekatan yang tidak hanya ekologis tetapi juga sosial budaya (M. Sayful, 2019).

Dampak negatif dari tambang pasir dengan sistem tambang terbuka ini terutama diakibatkan oleh degradasi lingkungan, perubahan geologi lingkungan antara lain kondisi estetika, topografi, kemiringan lereng, elevasi ketinggian, tersingkapnya batuan dasar, erosi, sedimentasi, kualitas dan kuantitas air tanah, penurunan produktivitas tanah, gangguan terhadap flora dan fauna, perubahan iklim mikro, serta bekas galian tambang pasir yang berbentuk kubangan besar tersebut seringkali memakan korban jiwa yang kebanyakan anak kecil yang tenggelam karena kubangan besar bekas galian tersebut dan akibat pertambangan pasir yang terus menerus mengakibatkan jalan umum di daerah sekitar pertambangan mengalami kerusakan yang parah dimana hal tersebut sangat merugikan masyarakat sekitar.

Telah banyak penelitian di Indonesia yang membahas tentang keberadaan tambang pasir, antara lain sebagai berikut. Penelitian terkait analisis dampak kebijakan tambang pasir pada umumnya tentang dilibatkan masyarakat setempat sehinga meningkatkan ekonomi, dimana Yoga Fratama (2020) menyimpulkan bahwa Dampak positif dari kegiatan pertambangan antara lain peluang kerja bagi masyarakat sekitar, peningkatan perekonomian, serta retribusi dan pajak yang dapat meningkatkan Pendapatan Asli Daerah. Adapun dampak negatifnya yaitu kerusakan lingkungan dan pencemaran, seperti debu, erosi, longsor dan bencana-bencana lainnya yang akan datang. 

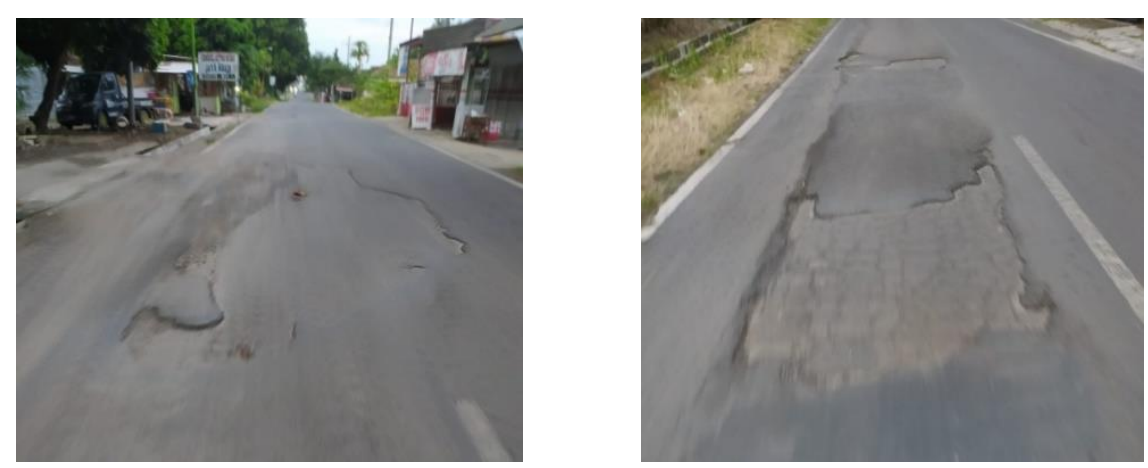

Gambar 2. Kerusakan jalan akibat aktivitas truk tambang pasir

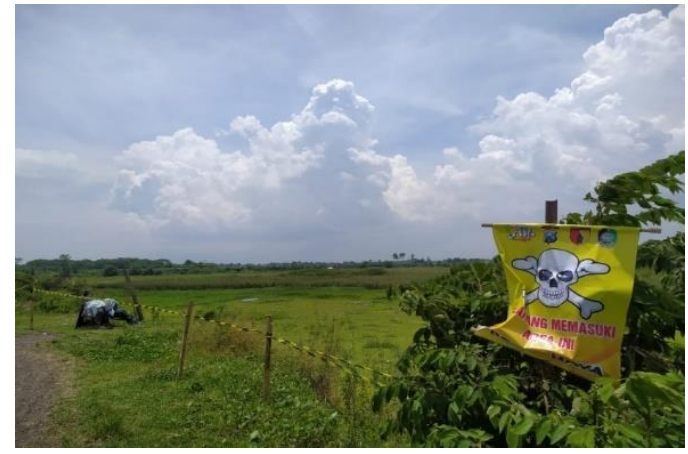

Gambar 3. Lokasi bekas galian tambang pasir memakan korban jiwa

Desi Yunita et al. (2016) menyimpulkan bahwa masyarakat yang semula merupakan entitas dalam solidaritas mekanis, berangsur-angsur berubah menjadi masyarakat yang lebih organik, dengan ciri yang tampak pada keinginan suatu kelompok untuk menguasai aset produksi pasir besi. Fakta menunjukkan bahwa pelarangan aktivitas pertambangan telah meningkatkan aktivitas ilegal yang tidak terkendali yang dampaknya sulit diukur. Upaya penyelamatan aset produksi harus diupayakan dengan mengambil alih pengelolaan sumber daya pasir besi dan membentuk badan ekonomi yang mewadahi, mengontrol, dan mendistribusikan hasil tambang oleh masyarakat tersebut, sehingga aktivitas penambangan pasir besi tersebut dapat dikendalikan.Penelitian terkait tambang pasir yang mengakibatkan konflik horizontal, Rahmat Andi Wiyanto (2015) menyimpulkan bahwa Keberadaan PT. Jogja Magasa Iron (PT. JMI) sebagai perusahaan tambang menuai respon pro dan kontra di kalangan masyarakat. Sehingga kehadiran konflik dalam penambangan pasir besi tidak bisa dihindari. Namun hal itu hanya bisa diminimalisir, terutama konflik horizontal antara masyarakat yang pro dengan masyarakat yang kontra dengan pihak kontra tambang.

Dari berbagai penjelasan diatas, terkait dampak yang diberikan oleh pertambangan pasir. Peneliti mencoba melakukan penelitian terkait dampak pertambangan pasir yang ada di kecamatan Rogojampi dan mencari solusi terkait bekas galian tambang yang dibiarkan menjadi kubangan besar oleh pihak penambangnya supaya bermanfaat bagi warga sekitar. Penelitian tersebut bejudul "Respon Masyarakat Terhadap Rencana Pemanfaatan Galian Tambang Pasir Sebagai Wahana Wisata Kolam Pancing”.

\section{METODE PENELITIAN}

Metode yang digunakan pada penelitian ini yaitu metode penelitian kualitatif deskriptif, dengan Teknik pengumpulan data dengan metode angket/kuisioner yang diperkuat dengan teknik observasi, dokumentasi dan wawancara. Teknik analisis data yang digunakan dalam penelitian ini adalah analisis kualitatif. Analisi kualitatif digunakan untuk menafsirkan data yang didapatkan berdasarkan hasil wawancara terhadap warga sekitar tambang pasir. Subjek penelitian yaitu bekas galian tambang pasir yang berada di desa Badean kecamatan Rogojampi Kabupaten Banyuwangi.

\section{HASIL DAN PEMBAHASAN}

\section{Karakteristik responden}

Responden pada kajian ini adalah masyarakat yang bertempat tinggal di sekitar areal pertambangan pasir 
yang berjumlah 30 orang. Untuk melihat lebih jelas gambaran karakteristik responden yang mencakup jenis kelamin, usia, pendidikan dan pekerjaan, dapat dijelaskan sebagai berikut ini:

1. Jenis Kelamin Responden Berdasarkan kuesioner yang telah disebarkan kepada 30 orang responden, diperoleh hasil berdasarkan jenis kelamin, sebanyak $80 \%$ adalah laki-laki, dan $20 \%$ adalah perempuan.

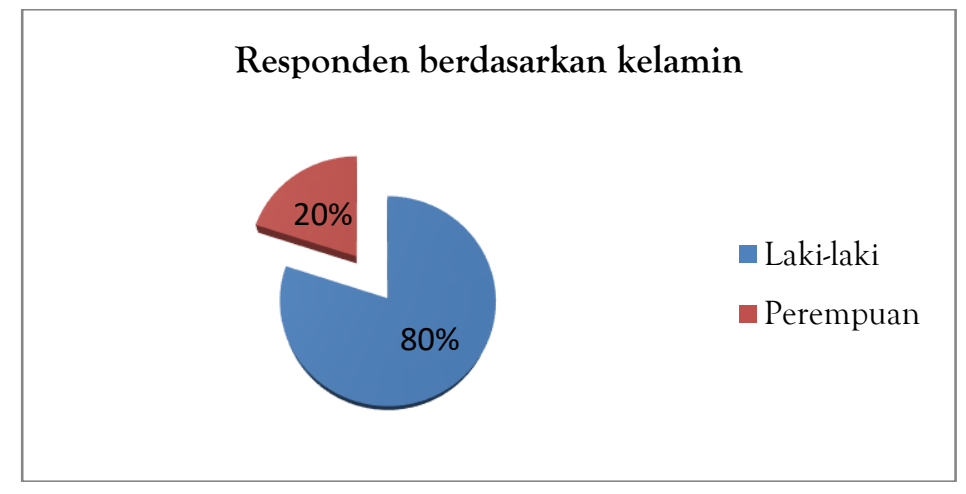

Gambar 4. Hasil responden berdasarkan kelamin.

2. Usia Responden Didapatkan hasil yaitu responden dengan klasifikasi usia 21-30 tahun mendominasi jumlah responden yaitu sebanyak 35\%, usia 31-40 tahun sebanyak 29\%, usia 41-50 tahun sebanyak 19\%, usia > 50 tahun sebanyak $17 \%$ dan untuk klasifikasi usia responden $<20$ tahun tidak ada.

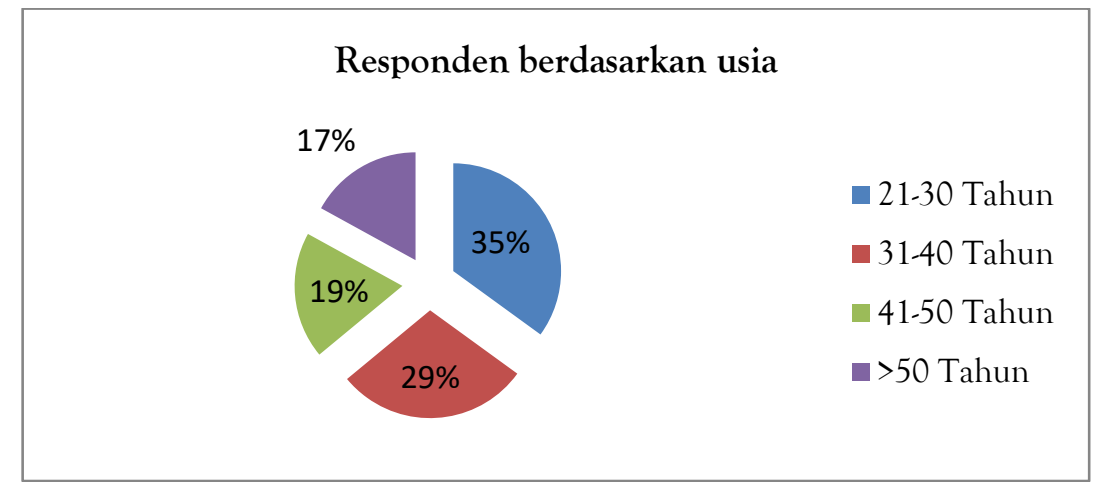

Gambar 5. Hasil responden berdasarkan usia.

3. Pendidikan Responden Karakteristik pendidikan masyarakat yang dijadikan responden dalam kajian ini adalah yang berpendidikan Tidak Tamat SD sebanyak $9 \%$ kemudian disusul dengan responden yang berpendidikan terakhir SD 31\%, SMP 29\%, berpendidikan SMA 26\% dan untuk tingkat pendidikan sarjana sebanyak $5 \%$.

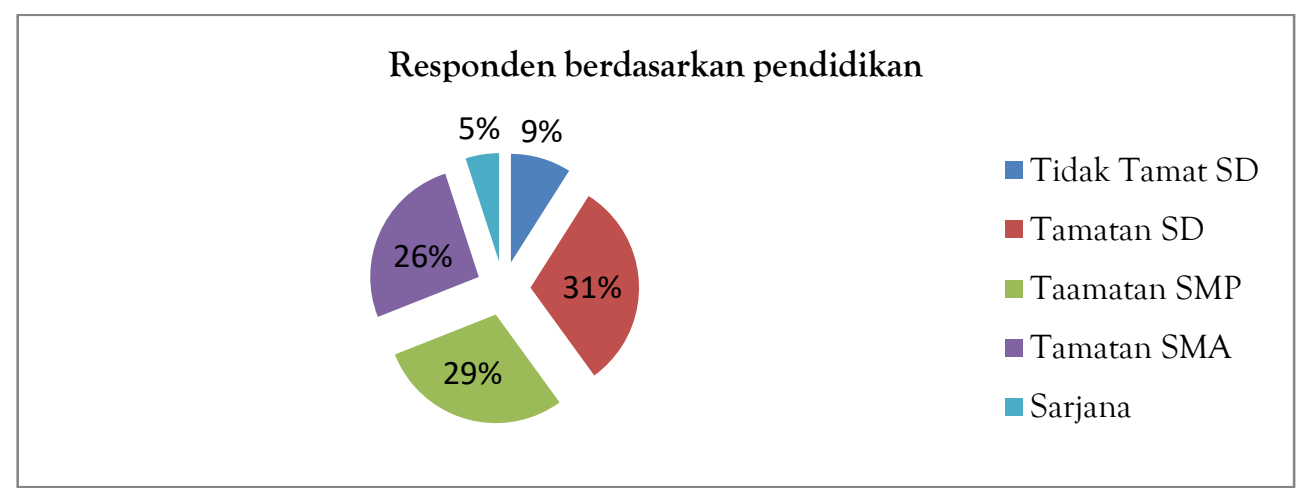

Gambar 6. Hasil Responden Berdasarkan Pendidikan.

4. Pekerjaan Responden Karakteristik Responden berdasarkan pekerjaan, masyarakat yang dijadikan responden pada kajian ini adalah mereka yang bekerja sebagai PNS sebanyak $10 \%$, responden yang bekerja sebagai Honorer sebanyak 9\%, responden yang bekerja sebagai Pensiunan sebanyak 5\%, sebagai Petani sebanyak 7\%, yang bekerja sebagai Wiraswasta sebanyak 36\%, yang bekerja sebagai Ibu Rumah Tangga sebanyak 7\%, 
responden yang bekerja sebagai Buruh Harian Lepas sebanyak 26\%.

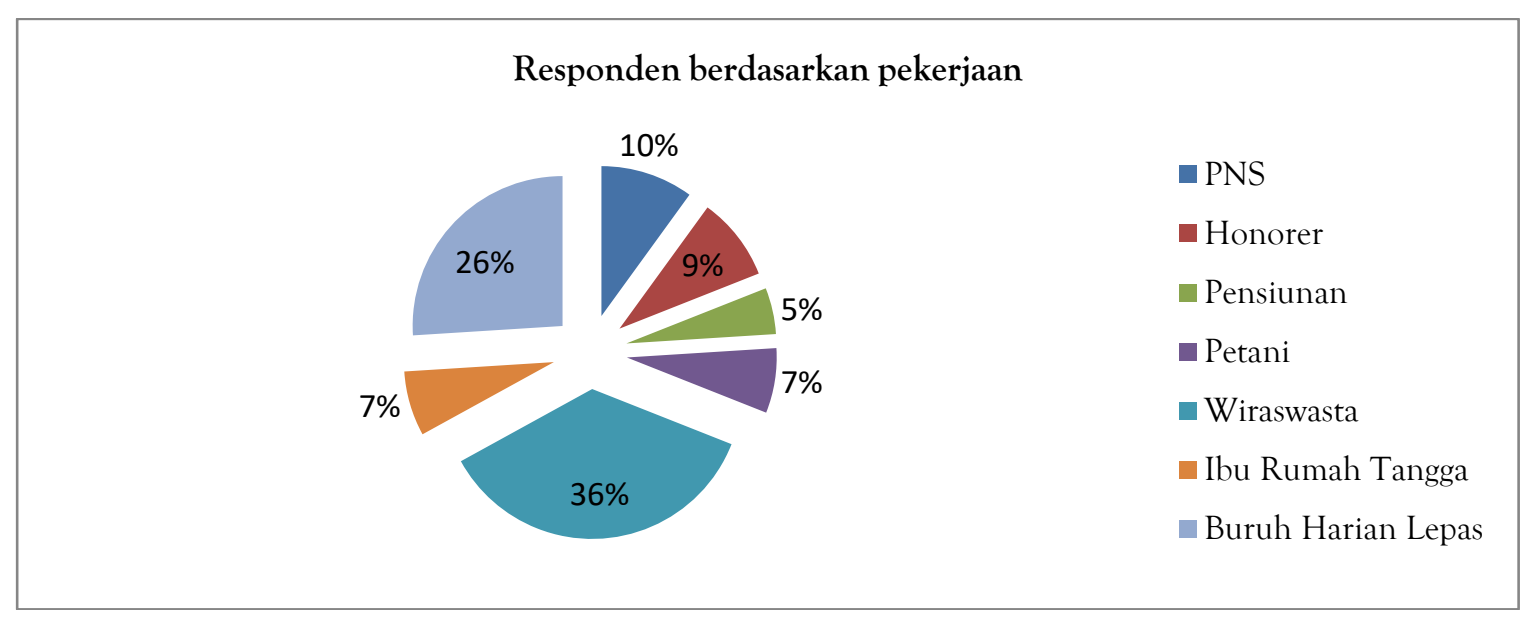

Gambar 7. Hasil responden berdasarkan pekerjaan.

\section{Respon masyarakat tentang bekas galian tambang pasir}

Pengetahuan responden tentang rencana penutupan tambang

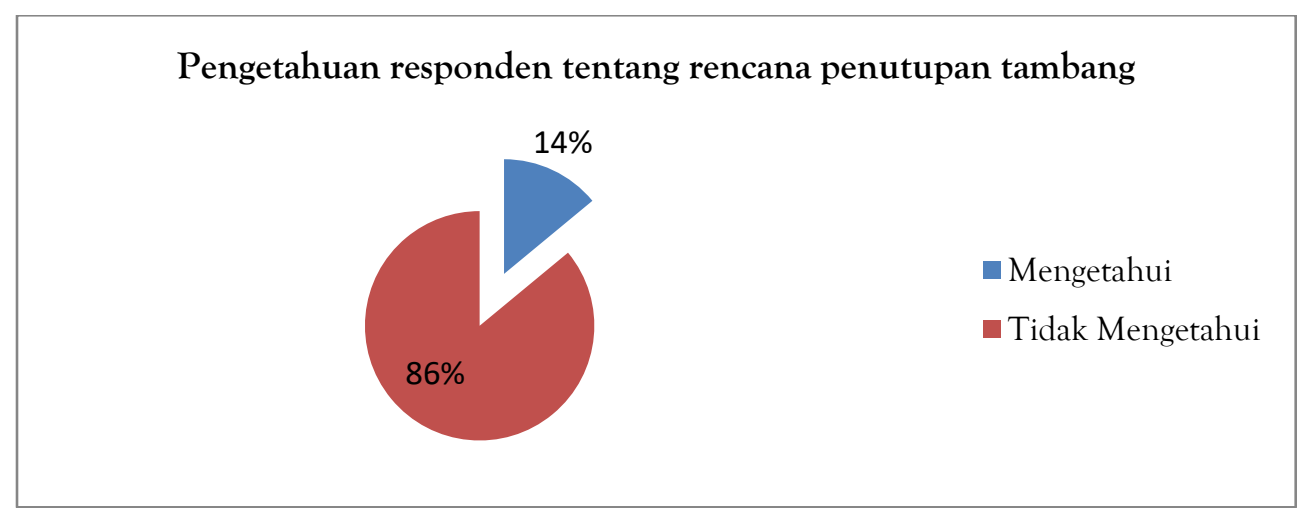

Gambar 8. Hasil pengetahuan responden tentang rencana penutupan tambang.

Dari responden berjumlah 30 orang, baik berdasarkan kriteria umur, pendidikan, dan pekerjaan, sebagian besar yaitu sekitar 26 responden (86\%) menyatakan ketidaktahuan akan rencana penutupan tambang. Karena pihak belum melakukan sosialisasi ke daerah responden, maka sebagian masyarakat juga mengharapkan adanya sosialisasi yang dilakukan oleh pihak tambang dengan pemuka masyarakat ke masyarakat, sehingga masyarakat mengetahui adanya rencana penutupan tambang. Dari pertanyaan yang diajukan mengenai bekas galian tambang yang ditinggalkan pada saat kegiatan tambang berakhir, 30 responden $(100 \%)$ menyatakan setuju dengan syarat, yaitu harus dikelola, atau dimanfaatkan untuk kepentingan masyarakat.

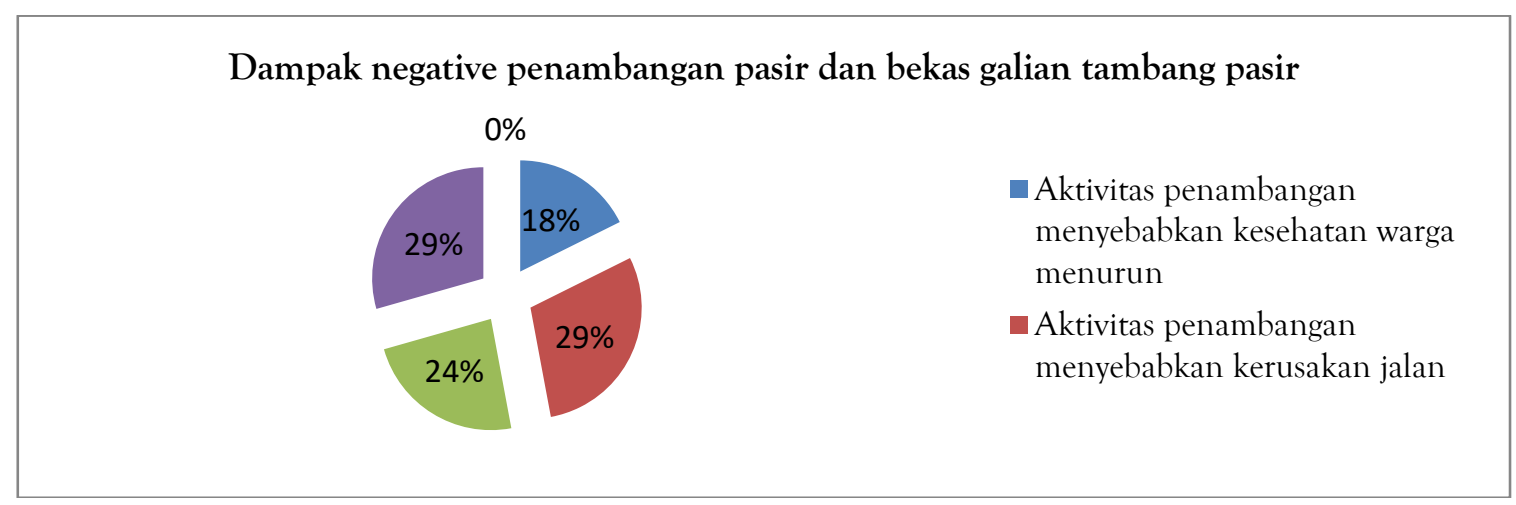

Gambar 9. Dampak negative penambangan pasir dan bekas galian tambang pasir.

Sesuai uraian gambar diatas bahwa aktivitas penambangan pasir dan bekas galian tambang pasir yang dibiarkan sangatlah berdampak negative bagi masyarakat, menurut hasil data yang didapatkan bahwa kegiatan 
penambangan pasir dan bekas galian pasir tersebut sangat merugikan masyarakat sekitar khususnya masyrakat desa Badean Kecamatan Rogojampi Kabupaten Banyuwangi, sisi negative yang diterima oleh masyrakat diantaranya, aktivitas penambangan pasirdapat mengganggu kesehatan, rusaknya jalan akibat aktivitas truk penambang pasir, kenyamanan masyarakat meresa terganggu dan juga bekas galian tambang pasir di daerah tersebut pernah memakan korban jiwa dimana korbannya anak kecil.

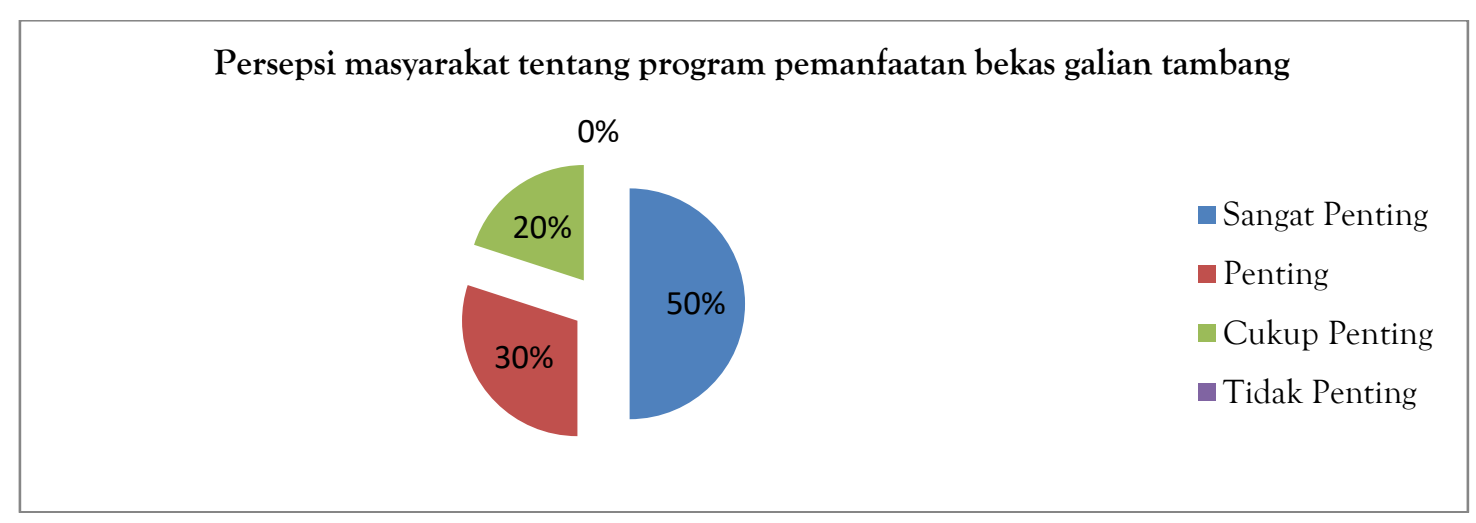

Gambar 10. Persepsi masyarakat tentang program pemanfaatan bekas galian tambang.

Dari hasil kuesioner yang dilakukan, responden juga menyatakan bahwa program pemanfaatan lubang bekas tambang sangat penting dan sebaiknya diarahkan dalam bentuk pemberdayaan masyarakat sekitar tambang, seperti terlihat pada gambar diatas.

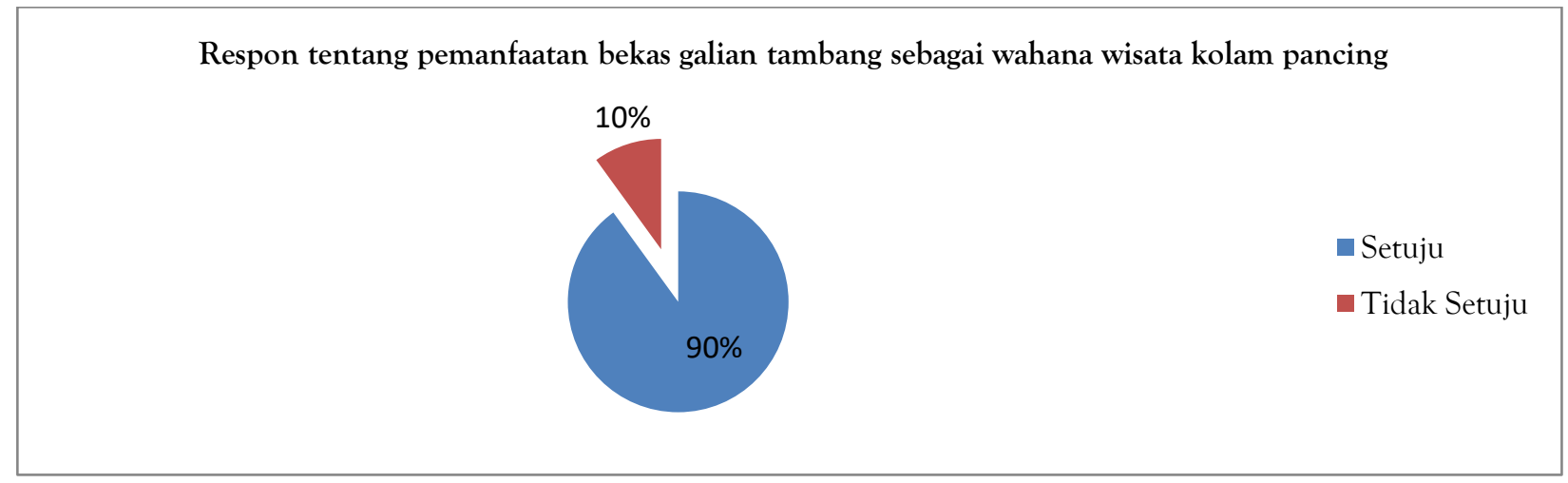

Gambar 11. Respon pemanfaatan bekas galian tambang sebagai wahana wisata kolam pancing.

Dibalik setiap permasalahan tentunya masih ada solusi yang dapat diberikan meskipun tidak langsung menyelesaikan permasalahan yang ada, maka dari itu harus ada program pemanfaatan bekas galian tambang sebagai wahana kolam pancing yang dikelola warga sendiri. Dari hasil kuesioner yang dilakukan, sebagian besar responden (90\%) menyatakan setuju bahwa program pemanfaatan lubang bekas galian tambang pasir sebagai wahana wisata kolam pancing, dengan harapan masyarakat mmendapatkan penghasilan tambahan dari program pemanfaatan bekas galian tambang pasir sebagai waha wisata kolam pancing. seperti terlihat pada gambar diatas.

Harapan responden tentang pemanfaatan bekas galian tambang sebagai wahana wisata kolam pancing

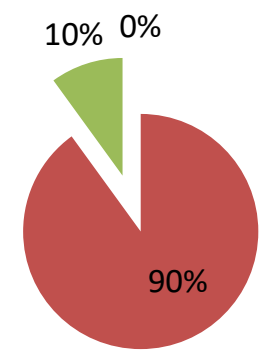

- Mata Pencaharian Pokok

- Mata Pencaharian Tambahan

- Tidak Menjawab

Gambar 12. Harapan responden pemanfaatan bekas galian tambang sebagai wahana wisata kolam pancing. 
Menurut Penelitian yang dilakukan oleh Tiyas nurcahyani. (2011) Manfaat lubang bekas tambang (void) terhadap pembangunan berkelanjutan dapat dilihat dari tiga aspek, yaitu: (a) Secara ekonomi: sumber air bersih, tempat wisata, perikanan, sumber air untuk pengairan tanaman. (b) Secar sosial: meningkatnya akses kesehatan masyarakat melalui tersedianya air bersih. (c) Secara lingkungan: kualitas air sesuai dengan baku mutu yang ditetapkan, sehingga akan kembalinya fungsi lingkungan dan ekosistem. Menurut Penelitian yang dilakukan oleh Fitri Qolbina et all. (2017) Kesimpulan hasil penelitian yang telah dilakukan diantaranya: (a) Diharapkan agar pemilik tambang pasir di desa petapahan kecamatan tapung kabupaten Kampar lebih memperhatikan lingkungan sekitar penambangan, terkait dengan jangka panjang dampak dari penambangan tersebut. (b) Perlunya perhatian pemerintah agar memperhatikan pertambangan yang kerap menjadi konflik di tengah masyarakat, dengan cara tidak terburu-buru memberikan izin kepada pihak pertambangan untuk mengekploitasi di daerah tersebut. (c) Diharapkan kepada pemerintah agar memperhatikan dampak lingkungan akibat adanya penambangan pasir dalam rangka meningkatkan pendapatan masyarakat supaya lebih tertata dengan baik.

Menurut hasil penelitian yang di lakukan oleh Dyahwanti, Inarni Nur (2007) bahwa agar dapat mengurangi dampak negative bekas galian tambang, peneliti menyusun beberapa kegiatan, yaitu : (a) Kegiatan mewujudkan budaya sadar dan kepedulian lingkungan pada segenap stakeholders yang terlibat dalam kegiatan agrowisata, (b) Kegiatan melokalisasi dan menghentikan kegiatan penambangan, (c) Kegiatan sistem pertanian berwawasan lingkungan dan bersifat agribnis, (d) Kegiatan reklamasi lahan bekas penambangan pasir secara terpadu, (e) Kegiatan pembangunan sarana dan prasarana lokasi agrowisata dengan melibatkan masyarakat setempat, (f) Kegiatan promosi kepariwisataan dengan melibatkan masyarakat setempat, (g) Kegiatan agrowisata berwawasan lingkungan dan berbasis masyarakat, (h) Kegiatan monitoring, evaluasi dan pelaporan, (i) Kegiatan Pemberdayaan Masyarakat dalam Agrowisata. Menurut hasil penelitian yang di lakukan oleh Budi Azwar (2016) hasil kajian penelitian yang dialakukan diantaranya: (a) Keberadaan tambang galian C di Kelurahan Pasir Sialang Kecamatan Bangkinang memberikan dampak positif maupun negatif, baik terhadap lingkungan terhadap kondisi sosial ekonomi masyarakat maupun pembangunan infrastruktur Kelurahan. (b) Kegiatan pertambangan galian C di Kelurahan Pasir Sialang Kecamatan Bangkinang yang dilakukan oleh perusahaan dengan melihat potensi alam yang banyak berupa galian $\mathrm{C}$ serta didukung oleh lokasi yang sangat strategis untuk melakukan pemasaran hasil tambang.

Berdasarkan hasil penelitian Dimas Sulistyo Sunarto et al. (2020) dapat disimpulkan bahwa ada tiga jenis kegiatan produktif anak di tambang pasir yaitu menjadi penambang pasir, kuli angkut, dan penjaga portal. Di mana menjadi penambang pasir adalah jenis kegiatan produktif yang paling banyak diminati. Alasan yang paling dominan membuat anak memilih bekerja di tambang pasir daripada di sektor lain adalah karena kegiatan produktif di tambang pasir tidak memerlukan keterampilan khusus. Faktor yang mempengaruhi anak putus sekolah adalah karena tidak ada biaya, hal tersebut membuat anak tertarik untuk melakukan kegiatan produktif ditambang pasir karena kemudahan dalam bekerja. Kemudahan tersebut membuat anak memilih untuk menjadikan kegiatan produktif di tambang pasir menjadi pekerjaan utama. Sehingga menurunkan minat anak untuk melanjutkan kependidikan selanjutnya sehingga lebih memilih bekerja ditambang pasir.

Dari beberapa penelitian yang sudah dilakukan sebelumnya terkait dampak negatif bekas galian tambang pasir dan bagaimana solusi memanfaatkan bekas galian tambang pasir, Penulis mencoba melakukan penelitian terkait pemanfaatan bekas galian tambang pasir yang berada di desa Badean kecamatan Rogojampi Kabupaten Banyuwangi dimana mendapatkan hasil penelitian bahwa hampir semua lubang bekas galian tambang pasir di kecamatan Rogojampi di biarkan begitu saja maka dari itu peneliti berinisiatif membuat program yaitu memanfaatkan bekas galian tambang pasir sebagai wahana wisata kolam pancing. Setelah dilakukannya penyebaran kuisoner terhadap beberapa responden yaitu masyarakat sekitar tambang pasir di desa badean kecamatan Rogojampi Kabupaten Banyuwangi mendapatkan respon baik. Bahwa sebagian Responden menyetujui akan program pemanfaatan bekas galian tambang pasir sebagai wahana wisata kolam pancing, dengan harapan masyarakat sekitar mendapatkan penghasilan tambahan yang itu dapat mengembangkan SDM masyarakat sekitar tambang pasir.

\section{SIMPULAN}

Dari hasil kajian dan pembahasan maka dapat ditarik kesimpulan sebagai berikut:

1. kegiatan penambangan pasir dan bekas galian pasir tersebut sangat merugikan masyarakat sekitar khususnya 
masyrakat desa Badean Kecamatan Rogojampi Kabupaten Banyuwangi, sisi negative yang diterima oleh masyrakat diantaranya, aktivitas penambangan pasir dapat mengganggu kesehatan, rusaknya jalan akibat aktivitas truk penambang pasir, kenyamanan masyarakat meresa terganggu dan juga bekas galian tambang pasir di daerah tersebut pernah memakan korban jiwa dimana korbannya anak kecil.

2. Sebagian besar responden (90\%) yaitu masyarakat sekitar bekas galian tambang di desa Badean Kecamatan Rogojampi Kabupaten Banyuwangi menyatakan setuju bahwa program pemanfaatan lubang bekas galian tambang pasir sebagai wahana wisata kolam pancing, dengan harapan masyarakat mmendapatkan penghasilan tambahan dari program pemanfaatan bekas galian tambang pasir sebagai waha wisata kolam pancing.

\section{Daftar Pustaka}

Akbar, P.S. \& Usman, H. 2009. Metode Penelitian Sosial. Jakarta: Bumi Aksara.

Arikunto, S. 2011. Prosedur Penelitian Suatu Pendekatan Praktik. Jakarta: Rineka Cipta.

Budi Azwar. 2016. Respon Masyarakat Terhadap Dampak Tambang Galian C Di Kelurahan Pasir Sialang Kecamatan Bangkinang. Prosiding Seminar Nasional "Pelestarian Lingkungan \& Mitigasi Bencana". ISBN 978-979-792-675-5. http://repositori.unri.ac.id/

Bog dan, Robert C. \& Sari Knopp Biklen. 1982. Qualitative Research for Education:An Introduction to Theory and Methods. Boston: Allyn and Bacon, Inc.

Dimas Sulistyo Sunarto, Agus Purnomo, Siti Malikhah Towaf. 2020. Dampak Kegiatan Produktif Di Tambang Pasir Terhadap Angka Anak Putus Sekolah Pada Jenjang Smp. Jurnal Pendidikan Ilmu Sosial. Vol, 30 No.1.

Desi Yunita, et al. (2016). Eksploitasi Pasir Besi dan Dampak Lingkungan Sosial, Budaya, Ekonomi pada Masyarakat di Pesisir Pantai Selatan Jawa Barat. Sosioglobal: Jurnal Pemikiran dan Penelitian Sosiologi, Universitas Padjadjaran, 1(1), hlm. 14-32. doi:https://doi.org/10.24198/isg.v1i1.11183.

Dyahwanti, Inarni Nur (2007). Kajian Dampak Lingkungan Kegiatan Penambangan Pasir Pada Daerah Sabuk Hijau Gunung Sumbing Di Kabupaten Temanggung. (Tesis Magister, Universitas Diponegoro, 2007) Diakses dari http://eprints.undip.ac.id/17783/

Fitri Qolbina, Hendro Ekwarso \& Ufira Isbah. 2017. Dampak Kegiatan Pertambangan Pasir Terhadap Pendapatan Keluarga Pemilik Tambang Didesa Petapahan Kecamatan Tapung Kabupaten Kampar. JOM Fekon. Vol.4 No.1

Irfan Ido. (2019). Dampak Usaha Kegiatan Penambangan Pasir terhadap Perubahan Mata Pencaharian di Kabupaten Muna Barat. Journal Publicuho, Universitas Halu Oleo, 2(1), hlm. 30-37. doi: http://dx.doi.org/10.35817/jpu.v2i1.5941.

KEHATI, 2009. Materi Kursus Inventarisasi Flora dan Fauna Taman Nasional Meru Betiri. Malang.

Muhammad Akbar., Zainal Said., \& R. Rusnaena. (2019). Implikasi Penambangan Pasir dalam Meningkatkan Perekonomian Masyarakat Padaidi Kab. Pinrang. Banco: Jurnal Manajemen dan Perbankan Syariah, Institut Agama Islam Negeri Parepare, 1(2), hlm. 59-69. doi:https://doi.org/10.35905/banco.v1i2.1304.

M. Sayful. (2019). Interaksi Sosial dan Reproduksi Nilai Budaya Masyarakat Nelayan di Pelabuhan Paotere Kota Makassar. Sosioreligius: Jurnal Ilmiah Sosiologi Agama, Universitas Islam Negeri Alauddin Makassar, 4(2), hlm. 42-60.

Nawawi, H. 2012. Metode Penelitian Bidang Sosial. Yogyakarta: Gajah Mada University Press.

Rahmat Andi Wiyanto. (2015). "Konflik Penambangan Pasir Besi di Desa Garongan Kecamatan Panjatan Kabupaten Kulon Progo”. Skripsi. Fakultas Ilmu Sosial dan Humaniora Universitas Islam Negeri Sunan Kalijaga, Yogyakarta.

Refki Hontong., Antonius Purwanto., \& Juliana Tumiwa. (2016). Konflik Sosial dalam Aktifitas Tambang Galian C di Desa Tateli Tiga. Acta Diurna Komunikasi, Universitas Sam Ratulangi, 5(5), hlm. 1-14. 
Salim, H.S. 2014. Hukum Pertambangan Mineral dan Batubara. Jakarta: Sinar Grafika.

Sugiyono. 2013. Metode Penelitian Pendidikan (Pendekatan Kuantitatif, Kualitatif, dan REDD). Bandung: Alfabeta.

Sugiyono, 2017. Metode Penelitian Kuantiatif, Kualitatif, dan R\&D. Bandung: Alfabeta.

Strauss, Anselm dan Yuliet Corbin. 2007. Dasar-dasar Penelitian Kualitatif. Yogyakarta: Pustaka Pelajar.

Tiyas nurcahyani. (2011). Kajian Pemanfaatan Lubang Bekas Tambang (Void) Di Pt Adaro Indonesia, Provinsi Kalimantan Selatan. (Tesis Magister, Universitas Indonesia, 2011) Diakses dari http://lib.ui.ac.id/detail.jsp?id=20295138

Yoga Fratama. (2020). "Upaya Pemerintah dalam Menanggulangi Dampak Galian Tambang Type C (Studi Kecamatan Sekernan Kabupaten Muaro Jambi)”. Skripsi. Fakultas Syariah, Universitas Islam Negeri Sulthan Thaha Saifuddin, Jambi. 